\title{
Can allelopathically active submerged macrophytes stabilise clear-water states in shallow lakes?
}

\author{
Sabine Hilt ${ }^{\mathrm{a}, *}$, Elisabeth M. Gross ${ }^{\mathrm{b}}$ \\ ${ }^{a}$ Leibniz Institute of Freshwater Ecology and Inland Fisheries Berlin, Müggelseedamm 301, 12587 Berlin, Germany \\ ${ }^{\mathrm{b}}$ Limnological Institute, University of Konstanz, P.O. Box 5560 M659, D 78457 Konstanz, Germany
}

Received 28 November 2006; accepted 27 April 2007

\begin{abstract}
Inhibition of phytoplankton by allelochemicals released by submerged macrophytes is supposed to be one of the mechanisms that contribute to the stabilisation of clear-water states in shallow lakes. The relevance of this process at ecosystem level, however, is debated because in situ evidence is difficult to achieve. Our literature review indicates that allelopathically active species such as Myriophyllum, Ceratophyllum, Elodea and Najas or certain charophytes are among the most frequent submerged macrophytes in temperate shallow lakes. The most common experimental approach for allelopathic interference between macrophytes and phytoplankton has been the use of plant extracts or purified plant compounds. Final evidence, however, requires combination with more realistic in situ experiments. Such investigations have successfully been performed with selected species. In situ allelopathic activity is also influenced by the fact that phytoplankton species exhibit differential sensitivity against allelochemicals both between and within major taxonomic groups such as diatoms, cyanobacteria and chlorophytes. In general, epiphytic species apparently are less sensitive towards allelochemicals than phytoplankton despite living closely attached to the plants and being of key importance for macrophyte growth due to their shading. Light and nutrient availability potentially influence the sensitivity of target algae and cyanobacteria. Whether or not additional stressors such as nutrient limitation enhance or dampen allelopathic interactions still has to be clarified. We strongly propose allelopathy as an important mechanism in the interaction between submerged macrophytes and phytoplankton in shallow lakes based on the frequent occurrence of active species and the knowledge of potential target species. The role of allelopathy interfering with epiphyton development is less well understood. Including further levels of complexity, such as nutrient interference, grazing and climate, will extend this ecosystem-based view of in situ allelopathy.
\end{abstract}

\section{Zusammenfassung}

Die Inhibition von Phytoplankton durch Allelochemikalien aus submersen Makrophyten ist einer der potentiellen Mechanismen, die zur Stabilisierung von Klarwasserzuständen in Makrophyten-dominierten Flachseen beitragen. Die Relevanz dieses Prozesses auf Ökosystemebene ist jedoch umstritten, da der in situ Nachweis schwierig ist. Unsere Literaturübersicht zeigt, dass allelopathisch aktive Arten wie Myriophyllum, Ceratophyllum, Elodea und Najas sowie bestimmte Characeen zu den häufigsten submersen Makrophyten in Flachseen der gemäßigten Breiten gehören. Der experimentelle Nachweis allelopathischer Effekte auf Phytoplankton erfolgte bisher überwiegend durch Pflanzenextrakte oder aufgereinigte Substanzen. Ein endgültiger Beweis erfordert jedoch zusätzlich Experimente unter in situ Bedingungen,

${ }^{*}$ Corresponding author. Tel.: + 493064181677 ; fax: +493064181682.

E mail addresses: hilt@igb berlin.de (S. Hilt, nee Korner), Elisabeth.gross@uni konstanz.de (E.M. Gross). 
die bisher nur für einige Arten verfügbar sind. Die allelopathische Aktivität in situ wird auch durch die differentielle Sensitivität der Phytoplanktonarten gegenüber Allelochemikalien beeinflusst, die sowohl zwischen als auch innerhalb verschiedener Gruppen wie Diatomeen, Grünalgen und Cyanobakterien nachgewiesen wurde. Epiphytische Arten erscheinen im Allgemeinen weniger durch Allelochemikalien beeinflusst als planktische, obwohl sie direkt auf der Pflanzenoberfläche leben und durch ihre Beschattung eine Schlüsselrolle für das Wachstum der Makrophyten spielen. Licht- und Nährstoffverfügbarkeit können die Sensitivität des Phytoplanktons beeinflussen. Ob zusätzlicher Stress z.B. durch Phosphatlimitation allelopathische Interaktionen verstärkt oder abschwächt, muss noch geklärt werden. Aufgrund des derzeitigen Wissensstandes zur Häufigkeit allelopathisch aktiver submerser Makrophytenarten sowie der Sensitivität der Zielorganismen halten wir Allelopathie für einen wichtigen Mechanismus in der Interaktion zwischen submersen Makrophyten und Phytoplankton in Flachseen. Die Rolle der Allelopathie bei der Beeinflussung der Epiphytonentwicklung ist dagegen bisher weniger gut verstanden. Die Einbeziehung weiterer komplexer Ebenen wie Nährstoffinteraktionen, Grazing und Klimaänderungen wird unsere Ökosystem-basierte Sicht allelopathischer in situ Aktivität weiter vertiefen.

Keywords: Allelopathy; Shallow lakes; Bistability; Alternative stable states; Submerged macrophytes; In situ evidence; Phytoplankton; Epiphytes

\section{Introduction}

Most of the world's lakes are small and shallow (Wetzel, 1990), and many of them display two strongly contrasting states: a clear state dominated by aquatic vegetation, and a turbid state characterised by a high phytoplankton biomass. These states represent alternative equilibria due to stabilising mechanisms that tend to keep the system in either the vegetation dominated or the phytoplankton-dominated state. Shifts between these equilibria are generally abrupt and difficult to reverse (Scheffer, Hosper, Meijer, Moss, \& Jeppesen, 1993). A loss of submerged vegetation and a switch to the turbid state have often been documented in temperate shallow lakes in response to eutrophication (Blindow, 1992; Körner, 2002; Sand-Jensen, Riis, Vestergaard, \& Larsen, 2000). Both shading by phytoplankton and/or epiphyton (attached algae growing on the plants' surfaces) seem to be responsible for the disappearance of submerged macrophytes. Phillips, Eminson, and Moss (1978) already argued that a nutrient-mediated increase in the density of epiphyton rather than an increase of phytoplankton is the most important factor for the loss of submerged macrophytes. The detrimental role of epiphyton (Jones \& Sayer, 2003) may be due to competition for light and carbon dioxide (Jones, Eaton, \& Hardwick, 2000). Reduced macrophyte growth then results in less negative effects on phytoplankton and ultimately in turbid conditions.

The negative effect of submerged macrophytes on phytoplankton may depend on various mechanisms: provision of refuge for phytoplankton-grazing zooplankton against predation by planktivorous fish, reduced nutrient availability, increased sinking losses, reduced light availability, and the release of allelopathically active substances (Scheffer et al., 1993). The latter is subject of much debate because final proof for allelopathy in situ is difficult or even inaccessible (Gross, Hilt, Lombardo, \& Mulderij, 2007). Several authors independently suggested a possible involvement of allelopathy behind observed phytoplankton patterns in whole-lake studies of vegetated, shallow lakes (Blindow et al., 2002; Lombardo, 2005; Mjelde \& Faafeng, 1997). However, none could provide any evidence in favour of or against allelopathy, and the debate on the role of allelopathy at ecosystem level remains open.

We reviewed the available literature in order to assess the ability of submerged macrophytes to significantly suppress phytoplankton growth through the production and release of allelopathically active substances and the possible prevalence of this mechanism in eutrophic shallow lakes. The major focus is on community and ecosystem level effects. We specifically address the following questions:

(1) Which submerged macrophyte species exhibit allelopathic activity against phytoplankton, how frequent do they occur in shallow lakes and what macrophyte coverage is required for an effective phytoplankton inhibition?

(2) Are allelopathically active substances produced and released by aquatic macrophytes in sufficient quantity?

(3) Are the relevant phytoplankton (and epiphyton) species significantly inhibited by these substances?

(4) Which environmental factors may influence the allelopathic interference between submerged macrophytes and algae or cyanobacteria?

\section{Allelopathically active submerged macrophytes in shallow lakes}

\section{Active species}

Allelopathic effects of submerged macrophytes on phytoplankton have been shown for at least 37 species (Mulderij, 2006). Studies directly comparing the activity 
of submerged macrophytes against phytoplankton are, however, scarce. Ranking of macrophytes according to their allelopathic activity depends on the tested phytoplankton species (Nakai, Inoue, Hosomi, \& Murakami, 1999) and the concentration of the extracts (Elakovich \& Wooten, 1995). Differences of two orders of magnitude between the allelopathic activities of different macrophyte species were reported (Gross, 1995). In general, there are apparently a number of very active species in temperate regions such as Eurasian watermilfoil ( $M y r-$ iophyllum spicatum) and rigid hornwort (Ceratophyllum demersum), species with a medium activity (i.e., Elodea or Chara species), and species that exert little or no allelopathic activity such as most pondweeds (Table 1). This table is based on a wide array of different studies, mostly using different bioassay systems and culture conditions for both macrophytes and phytoplankton or epiphytes. Therefore, this provisional ranking will certainly change with more information, e.g., on the impact of resources both on the macrophyte and the target algae or cyanobacteria. At present, it is mainly based on few studies, which compare several macrophytes using comparable bioassay systems.

\section{Frequency of occurrence in shallow eutrophic lakes}

Submerged macrophytes with a significant, laboratory proven allelopathic effect on phytoplankton should have an advantage over inactive species, which may be quantified as their percentage of occurrence in shallow eutrophic lakes. M. spicatum, C. demersum, Elodea spp., Najas marina and certain Chara species indeed often are among the 10 most common submerged macrophytes in lakes in Germany, Denmark, The Netherlands and Ireland (Table 2). Allelopathically active submerged macrophytes were present in $65 \%$ of 212 shallow lakes (mean depth $\leqslant 5 \mathrm{~m}$ ) in Mecklenburg-Western Pomerania (data from Leske, Berg, Kabus, \& Täuscher, 2005). The proportion of lakes containing any of those species increased with species richness and reached $100 \%$ at seven or more species (Fig. 1). Allelopathically active species represented $27-52 \%$ of all species present (Fig. 1), thus were more frequent (in terms of numbers) than their numerical proportion $(21 \%)$ of 19 active species among 89 species in total. No significant correlation was found between the percentage of allelopathically active species and the total species number, lake size or mean depth.

Sago pondweed (Potamogeton pectinatus) is a species with a high abundance (Table 2) despite low allelopathic activity. This species often remains in lakes even during hypertrophic periods (Körner, 2001; Ozimek, Prejs, \& Prejs, 1986), and often expands first during re-oligotrophication (Köhler et al., 2005). Alternative strategies to escape local extinction in turbid waters include canopy forming, i.e., most of the biomass is located

Table 1. Ranking of submerged macrophyte species of the temperate region according to their allelopathic activity against phytoplankton

\begin{tabular}{|c|c|c|c|}
\hline $\begin{array}{l}\text { Allelopathic } \\
\text { potential }\end{array}$ & Macrophyte species & Active compounds & References \\
\hline \multirow[t]{2}{*}{ High } & Myriophyllum spicatum & $\begin{array}{l}\text { Polyphenols (hydrolysable } \\
\text { tannins), tellimagrandin II }\end{array}$ & $1,2,3,4,5,6,7,8$ \\
\hline & Ceratophyllum demersum & $\begin{array}{l}\text { Elemental sulphur, labile } \\
\text { sulphur compounds, unknown }\end{array}$ & $4,6,9,10,11,12$ \\
\hline \multirow[t]{5}{*}{ Medium } & Elodea canadensis/E. nuttallii & $\begin{array}{l}\text { Phenolic compound(s), } \\
\text { unknown }\end{array}$ & 11,13 \\
\hline & Najas marina subsp. intermedia & Unknown & 12 \\
\hline & Myriophyllum verticillatum & $\begin{array}{l}\text { Phenylpropanoid glucosides, } \\
\text { hydrolysable tannins }\end{array}$ & 14,15 \\
\hline & Stratiotes aloides & Unknown & $16,17,18,19,20$ \\
\hline & $\begin{array}{l}\text { Chara aspera, } C . \text { globularis, } C . \\
\text { tomentosa, C. contraria }\end{array}$ & Dithiane, trithiane, unknown & $21,22,23,24,25,26,27$ \\
\hline \multirow[t]{3}{*}{ Low or not present } & Potamogeton lucens & & 2 \\
\hline & P. crispus & & 6 \\
\hline & P. pectinatus & & 4,23 \\
\hline
\end{tabular}

1 Planas, Sarhan, Dube, Godmaire, and Cadieux (1981), 2 Jasser (1995); 3 Gross et al., (1996); 4 Korner and Nicklisch (2002), 5 Leu, Krieger Liszkay, Goussias, and Gross (2002); 6 Nakai et al. (1999); 7 Nakai, Inoue, Hosomi, and Murakami (2000); 8 Nakai, Inoue, and Hosomi (2001); 9 Kogan and Chinnova (1972); 10 Wium Andersen et al. (1983); 11 Wium Andersen (1987); 12 Gross et al. (2003); 13 Erhard and Gross (2006); ${ }^{14}$ Aliotta, Molinaro, Monaco, Pinto, and Previtera (1992), ${ }^{15}$ Hilt et al. (2006), ${ }^{16}$ Jasser (1995), 17 Mulderij, Mooij, Smolders, and Van Donk (2005); 18 Mulderij, Mooij, and Van Donk (2005); 19 Mulderij, Smolders, and Van Donk (2006); 20 Mulderij, Mau, Van Donk, and Gross (2007); 21 Anthoni, Christophersen, Madsen, Wium Andersen, and Jacobsen (1980); 22 Wium Andersen et al. (1982); 23 Hootsmans and Blindow (1994); 24 Van Donk and Van de Bund (2002); 25 Berger and Schagerl (2003); 26 Berger and Schagerl (2004); 27 Mulderij, Van Donk, and Roelofs (2003). 
Table 2. Occurrence (\%) of the 10 most common submerged macrophyte species (allelopathically active species marked in bold)

\begin{tabular}{|c|c|c|c|c|c|c|c|c|c|}
\hline \multicolumn{2}{|l|}{ Ireland $^{\mathrm{a}}$} & \multicolumn{2}{|c|}{ The Netherlands ${ }^{\mathrm{b}}$} & \multicolumn{2}{|c|}{ Denmark $^{\mathrm{c}}$} & \multicolumn{2}{|c|}{ Germany $(\mathrm{B})^{\mathrm{d}}$} & \multicolumn{2}{|c|}{ Germany $(\mathrm{MW})^{\mathrm{e}}$} \\
\hline E. can. & 52 & E. nut. & 75 & P. pec. & 50 & C. dem. & 56 & C. dem. & 31 \\
\hline S. eme. & 33 & P. pec. & 53 & E. can. & 39 & M. spi. & 54 & U. vul. & 31 \\
\hline P. obt. & 33 & P. pus. & 47 & P. per. & 39 & S. alo. & 34 & M. spi. & 29 \\
\hline L. uni. & 30 & C. dem. & 40 & R. cir. & 38 & E. spp. & 23 & P. pec. & 27 \\
\hline P. ber. & 21 & P. luc. & 38 & M. spi. & 38 & P. per. & 22 & N. mar. & 20 \\
\hline P. alp. & 19 & R. cir. & 29 & P. cri. & 38 & C. spp. & 17 & P. per. & 19 \\
\hline P. per. & 18 & C. vul. & 26 & P. obt. & 38 & P. cri. & 12 & P. luc. & 19 \\
\hline P. cri. & 18 & P. cri. & 24 & P. ber. & 34 & F. ant. & 8 & R. cir. & 16 \\
\hline M. spi. & 15 & T. int. & 18 & C. dem. & 27 & U. spp. & 5 & C. glo. & 16 \\
\hline P. pus. & 14 & Z. pal. & 17 & S. eme. & 27 & P. pec. & 5 & C. tom. & 15 \\
\hline
\end{tabular}

In Ireland (574 lakes, 1976 1995), The Netherlands (101 floodplain lakes, 1999 2000), Denmark (82 lakes, 1983 1994), Germany (Brandenburg (B), 372 lakes, 1950s), Germany (Meckenburg Western Pomerania (MW), (434 lakes, 1956 2000) (C. dem.: Ceratophyllum demersum, C. glo.: Chara globularis, C. spp.: Chara spp., C. tom.: C. tomentosa, C. vul.: C. vulgaris, E. can.: Elodea canadensis, E. nut.: Elodea nuttallii, F. ant.: Fontinalis antipyretica, L. uni. Littorella uniflora, N. mar.: Najas marina, P. alp.: Potamogeton alpinus, P. ber.: P. berchtoldii, P. cri.: P. crispus, P. luc.: P. lucens, P. obt.: P. obtusifolius, P. pec.: P. pectinatus, P. per.: P. perfoliatus, M. spi.: Myriophyllum spicatum, P. pus.: P. pusillus, R. cir.: Ranunculus circinatus, S. eme.: Sparganium emersum, S. alo.: Stratiotes aloides, T. int.: Tolypella intricata, U. vul.: Utricularia vulgaris, Z. pal.: Zannichellia palustris.

${ }^{a}$ Heegaard, Birks, Gibson, Smith, and Wolfe Murphy (2001).

${ }^{\mathrm{b}}$ Van Geest et al. (2005).

${ }^{\mathrm{c}}$ Vestergaard and Sand Jensen (2000).

${ }^{\mathrm{d}}$ Korner (2002).

${ }^{\mathrm{e}}$ Leske, Berg, Kabus, and Tauscher (2005).

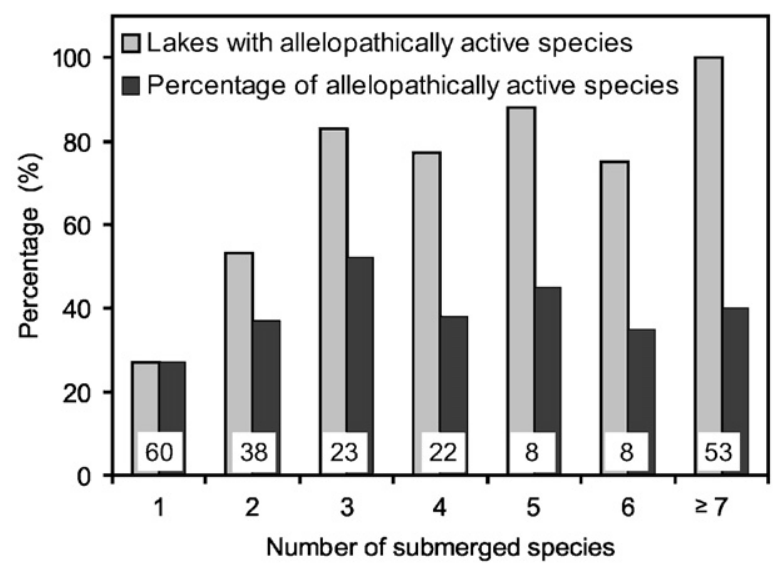

Fig. 1. Percentage of lakes with allelopathically active submerged macrophyte species and mean percentage of allelopathically active species in 212 shallow lakes (mean depth $\leqslant 5 \mathrm{~m}$ ) in Mecklenburg Western Pomerania (data from Leske et al., 2005). Total numbers of lakes are given at the base of the bars.

directly under the water surface and fast elongation in spring due to carbohydrate storage in tubers (Van Wijk, 1988). These strategies, however, are not exclusive of this species and are also used by allelopathically active species, such as C. demersum (Best \& Meulemans, 1979). Lombardo, Mjelde, Källqvist, and Brettum (unpublished) argued that laboratory-observed close-range allelopathic effects by $C$. demersum and, to a lesser extent, Elodea canadensis, were replaced by other strategies at the macrophyte-bed scale, including early growth onset in such species. The differential impact of allelopathy versus competition for light for the macrophytes Chara spp. and Stratiotes aloides has been modelled recently (Mulderij, Van Nes, \& Van Donk, 2007). Further in situ studies and modelling may help determining the relative contribution of each individual strategy including allelopathy to the successful survival of certain macrophyte species under eutrophic conditions.

\section{Macrophyte cover required for effective phytoplankton inhibition}

Negative effects of macrophytes on phytoplankton growth have been reported for macrophyte coverage values between $3 \%$ and $100 \%$ (Table 3 ). The relative importance of the different potential mechanisms for phytoplankton biomass reduction is likely to depend on climate, lake size and depth, plant community composition and density and nutrient concentrations (Jeppesen, Jensen, Søndergaard, \& Lauridsen, 1999; Moss, Madgwick, \& Phillips, 1997). Although not proven, a potential impact of allelopathy was considered in lakes with high macrophyte coverage values (Table 3). In laboratory macrophyte-phytoplankton coexistence experiments, significant allelopathic effects on phytoplankton were reported for macrophyte biomass densities between 1 and $10 \mathrm{~g}$ wet weight $\mathrm{L}^{-1}$ (; Körner \& Nicklisch, 2002; Nakai et al., 1999), which refers to a biomass of approximately $80-800 \mathrm{~g}^{2}$ dry weight $\mathrm{m}^{-2}$ in $1 \mathrm{~m}$ deep water. The biomass of submerged macrophytes in shallow eutrophic lakes can easily exceed these values. 
Table 3. Available studies on the effects of different submerged macrophyte coverage (based on total lake surface area) on phytoplankton growth in shallow lakes

\begin{tabular}{|c|c|c|}
\hline $\begin{array}{l}\text { Macrophyte } \\
\text { coverage } \\
(\%)\end{array}$ & $\begin{array}{l}\text { Mechanisms mentioned } \\
\text { to explain lower } \\
\text { phytoplankton biomass }\end{array}$ & References \\
\hline 100 & $\begin{array}{l}\text { Reduced resuspension, } \\
\text { nutrient uptake, } \\
\text { zooplankton grazing, } \\
\text { allelopathy }\end{array}$ & $\begin{array}{l}\text { Van den Berg et al. } \\
\text { (1998) }\end{array}$ \\
\hline$\geqslant 80$ & $\begin{array}{l}\text { Macrophyte induced } \\
\text { sediment nitrification, } \\
\text { competition for light, } \\
\text { zooplankton grazing }\end{array}$ & Ruggiero et al. (2003) \\
\hline 65 & $\begin{array}{l}\text { Increased sedimentation } \\
\text { rate, carbon limitation, } \\
\text { lower bioavailable } \\
\text { fraction of the total } \\
\text { amount of phosphorus, } \\
\text { allelopathy }\end{array}$ & $\begin{array}{l}\text { Blindow, Hargeby, and } \\
\text { Andersson (2002) }\end{array}$ \\
\hline$>50$ & $\begin{array}{l}\text { Nitrogen uptake, } \\
\text { enhanced sediment } \\
\text { denitrification, } \\
\text { zooplankton grazing }\end{array}$ & Meijer et al. (1994) \\
\hline 50 & $\begin{array}{l}\text { Competition for } \\
\text { inorganic nitrogen, } \\
\text { competition for light, } \\
\text { allelopathy }\end{array}$ & $\begin{array}{l}\text { Mjelde and Faafeng } \\
\text { (1997) }\end{array}$ \\
\hline$>30$ & $\begin{array}{l}\text { Increased zooplankton } \\
\text { grazing due to reduced } \\
\text { proportion of } \\
\text { planktivorous to } \\
\text { piscivorous fish }\end{array}$ & Jeppesen et al. (1990) \\
\hline $\begin{array}{l}>30(\text { plant } \\
\text { volume } \\
\text { infested })\end{array}$ & $\begin{array}{l}\text { Competition for } \\
\text { nutrients, reduced } \\
\text { nutrient cycling due to } \\
\text { reduced wind mixing and } \\
\text { resuspension, increased } \\
\text { sedimentation }\end{array}$ & Canfield et al. (1984) \\
\hline 2025 & $\begin{array}{l}\text { Reduced resuspension, } \\
\text { increased sedimentation, } \\
\text { competition for light, } \\
\text { allelopathy, nutrient } \\
\text { uptake }\end{array}$ & $\begin{array}{l}\text { Mjelde, Brettum, } \\
\text { Lombardo, and } \\
\text { Ptacnik (unpublished) }\end{array}$ \\
\hline 510 & Zooplankton grazing & $\begin{array}{l}\text { Portielje and Van der } \\
\text { Molen (1999) }\end{array}$ \\
\hline 5 & $\begin{array}{l}\text { Constant Daphnia } \\
\text { predation }\end{array}$ & Lau and Lane (2002) \\
\hline 3 & $\begin{array}{l}\text { Increased zooplankton } \\
\text { grazing (two fold } \\
\text { increase of the average } \\
\text { night time density of } \\
\text { cladocerans) }\end{array}$ & Lauridsen et al. (1996) \\
\hline
\end{tabular}

Standing crops of up to $1150 \mathrm{~g}$ dry weight $\mathrm{m}^{-2}$ are reported for the allelopathically active species $M$. spicatum (Grace \& Wetzel, 1978).

\section{Production and exudation of active substances in submerged macrophytes}

\section{Total content of active substances}

Although a number of allelopathically active substances were found in different macrophytes (Gross, 2003a), most are still unidentified (Table 1). $M$. spicatum, the best investigated species, contains up to $30 \%$ polyphenols based on dry weight and up to $6 \%$ of the major algicidal tellimagrandin II in apical meristems, the plant parts with highest polyphenol concentrations (Gross, Meyer, \& Schilling, 1996; Gross, unpublished results). Different seasonal patterns of polyphenol concentrations were found in $M$. spicatum, either high concentrations in summer in Lower Lake Constance (Gross, unpublished results) or stable concentrations throughout the season in small shallow experimental ponds (Gross, 2000). Tissue concentrations and excretion rates of polyphenolic compounds in Myriophyllum verticillatum from a shallow dystrophic lake were highest in spring (Hilt, Ghobrial, \& Gross, 2006). A high concentration of allelopathically active compounds in spring and early summer appears reasonable for rooted submerged plants as competition for light with phytoplankton is strongest at that time.

A more complex pattern, however, might arise when these compounds have further ecological activity averting abiotic or biotic stressors. Herbivory on M. spicatum apical meristems, which contain the highest concentrations of allelopathically active hydrolysable polyphenols, should severely hamper the negative impact on phytoplankton (Choi, Bareiss, Walenciak, \& Gross, 2002). The same polyphenols exert some antimicrobial activity (Walenciak, Zwisler, \& Gross, 2002), although other microbes are capable of their degradation (Müller, Hempel, Philipp, \& Gross, 2007). Light and UV light stress or nutrient limitations (see below) also affect secondary metabolites, among them allelopathically active polyphenols in M. spicatum (Gross, 2003b). It is not uncommon that plant secondary metabolites have multiple functions, which results in reduced costs for production and maintenance of these allelochemicals for the plant. Given the spatial and temporal variability of all biotic and abiotic factors, i.e., herbivory or resource interference, it is clear that no simple and general seasonal pattern of allelopathy can be expected.

\section{Effects of resource availability}

The carbon-nutrient balance hypothesis $(\mathrm{CNBH}$; Bryant, Chapin, \& Klein, 1983) predicting that the concentration of defensive compounds depends on the availability of nitrogen and light has been vigorously debated over the past years (Stamp, 2003). Gross 
(2003b) showed a distinct difference between the reaction of total phenolic compounds and tellimagrandin II in $M$. spicatum towards different light and nitrogen levels, indicating that the $\mathrm{CNBH}$ is not universally true for all phenolic compounds. Nitrogen availability did not influence the total contents of polyphenols whereas tellimagrandin II concentrations in $M$. spicatum increased at low nitrogen concentrations (Gross, 2003b). In M. verticillatum, low phosphorus concentrations correlated with high total polyphenol concentrations (Bauer, Blaschke, Gross, \& Hilt, unpublished). In $M$. spicatum and $M$. verticillatum, sunexposed shoots and especially apical meristems had higher concentrations of total phenolic compounds than shade-adapted plants (Choi et al., 2002; Bauer et al., unpublished). Accumulation of polyphenols during clear-water phases and profiting from these substances under turbid conditions might be an adaptive strategy of submerged macrophytes, but this scenario strongly depends on presently unknown turnover rates of polyphenols. Apparently, tellimagrandin II, in contrast to the pool of polyphenols, is also produced at high concentrations under low light conditions (Gross, 2003b). Overall, the assessment of light and nutrient effects on the variability of allelochemicals in submerged macrophytes requires deeper insights into their biosynthetic pathways and hierarchical levels (see below).

\section{Stability of exuded allelochemicals}

Allelopathically active substances are, after exudation, subjected to fast biotic (bacterial degradation) and/ or abiotic (light, oxygen; Appel, 1993) transformations. Photolytic processes contribute to changes of the allelopathic properties of macrophyte exudates, as photooxidation of organic material seems to be ubiquitous for all types of dissolved organic matter (Farjalla, Anesio, Bertilsson, \& Graneli, 2001; Graneli, Lindell, \& Tranvik, 1996). Yet, nothing is known about macrophyte allelochemicals. Many studies use axenic organisms to avoid bacterial metabolisation, because the presence of bacteria might cause a loss or change of the inhibitory activity of macrophyte exudates (Gross, 2003a; Gross et al., 1996; Nakai et al., 1999). When comparing the effect of tannic acid (TA), a hydrolysable polyphenol, on algae with or without bacteria, the inhibition decreased when bacteria were present (Bauer, Grossart, \& Hilt, unpublished). Pre-treatment of the natural bacterial community with TA resulted in a change of the natural bacterial community towards potentially TA-resistant or metabolising bacteria (Bauer et al., unpublished). Specific polyphenol-degrading bacteria, as recently isolated from $M$. spicatum, may have a strong impact on the inhibitory effect of the macrophyte exudates (Müller et al., 2007).

\section{Inhibition of phytoplankton and epiphytes}

\section{Proof of in vitro and in situ allelopathic activity}

Proving allelopathic effects of macrophytes on phytoplankton in an ecologically meaningful way is not easy. Experimental approaches mainly comprise the use of plant extracts, exudates or purified compounds and coexistence experiments or dialysis bag experiments at laboratory to field scale. None of these approaches per se addresses all of Willis' (1985) pre-requisites to prove allelopathy (Gross et al., 2007). One of the main problems is the in situ interference of allelopathy and nutrient competition, and it seems that separating both is not realistic (see above and Inderjit \& Del Moral, 1997). Lombardo et al. (unpublished) found that the observed inhibitory action on suspended algae in laboratory coexistence experiments may have been strongly influenced by nutrients. As a consequence, extracts or purified compounds are mostly used, although they least reflect the real conditions in lakes (Fig. 2). Final proof of allelopathy in situ requires a combination of experimental approaches from lab scale to ecosystem level, considering light and nutrient interference as well as grazing on both plants and algae.

\section{Species-specific sensitivity to allelochemicals}

Phytoplankton species often exhibit differential sensitivity against macrophytes allelochemicals (Gross, Erhard, \& Ivanyi, 2003; Jasser, 1995; Körner \& Nicklisch, 2002; Mulderij, Mooij, Smolders, \& Van Donk, 2005). When pooling all available literature data on planktonic and epiphytic species (Hilt, 2006; Hilt et al., 2006; Mulderij, Mooij, Smolders, et al., 2005; Mulderij, Mau, et al., 2007), diatoms and cyanobacteria are often significantly inhibited by allelochemicals of submerged macrophytes, whereas chlorophytes appear less sensitive (Fig. 3). A stronger allelopathic effect on diatoms and

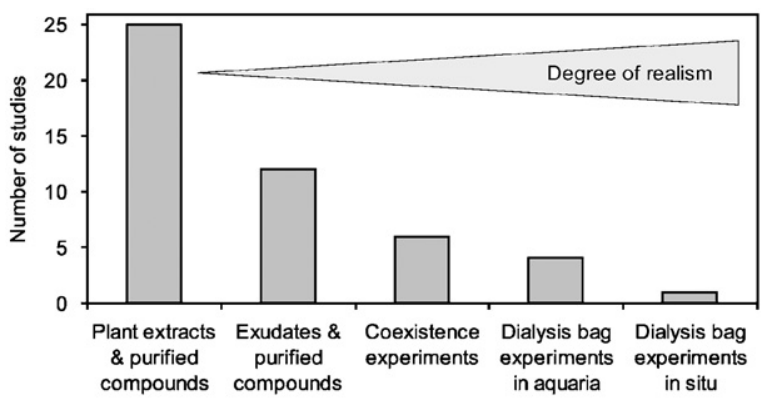

Fig. 2. Number of studies on the allelopathic effect of submerged macrophytes on algae and cyanobacteria using different methods (see Gross et al., 2007). The increasing degree of realism has been deduced from ecological theory and ecological concepts. 
cyanobacteria seems ecologically more reasonable because these groups are typically more abundant than chlorophytes in shallow lakes at total phosphorus (TP) concentrations below $100 \mu \mathrm{g} \mathrm{L}^{-1}$ (Jeppesen et al., 2005). Long-term stability of the macrophyte-dominated state can only be expected below a critical nutrient level, which has been suggested at $80-150 \mu \mathrm{g} \mathrm{TP} \mathrm{L}^{-1}$, depending on lake size and depth (Jeppesen et al., 1990). Remarkably, the sensitivity of cryptophytes and chrysophytes, present in higher abundance in shallow lakes after restoration measurements (Jeppesen et al., 2005) has not been studied in detail yet. Mjelde, Brettum, Lombardo, and Ptacnik (unpublished) have found that for a set of 19 meso-eutrophic shallow lakes in Norway, some dominated by the allelopathically active species $C$. demersum or E. canadensis, others unvegetated, cryptophyte and chrysophyte abundance patterns did not differ, indicating a low sensitivity towards macrophyte allelochemicals.

Among cyanobacteria, a higher sensitivity of members of the Oscillatoriales (Körner \& Nicklisch, 2002) and of toxic Microcystis strains as compared to nontoxic (Mulderij, Mooij, Smolders, et al., 2005) was found. For Microcystis, differences in sensitivity have been attributed to differences in the attached microbial biofilm (Casamatta \& Wickstrom, 2000) or energy allocation (Mulderij, 2006). Further mechanisms might be differences in cell wall properties, uptake mechanisms or lower sensitivity of target physiological processes (e.g., photosynthesis, exoenzymes). Thus an expansion of allelopathic studies not only towards community or ecosystem level but also towards a better understanding of genetic and physiological constraints would be helpful in explaining patterns. The differential sensitivity of phytoplankton species or even strains against macrophyte allelochemicals might be yet a neglected factor contributing to phytoplankton succession patterns.

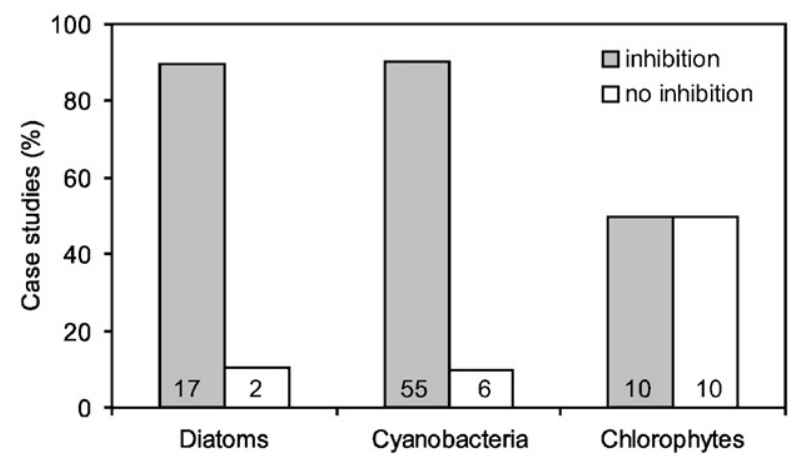

Fig. 3. Frequency of studies indicating inhibition (or lack thereof) exerted by submerged macrophytes on different phytoplankton groups (data from Hilt, 2006; Hilt et al., 2006; Mulderij, Mooij, et al., 2005; Mulderij, Mau, et al., 2007). Total case numbers are given at the base of the bars.

\section{Epiphytes versus phytoplankton}

Epiphyton density might be one of the key triggers of switches between alternative stable states in shallow lakes. Epiphytic algae and cyanobacteria are potentially the primary target of allelopathically active compounds of submerged plants as they live adjacent to the donor and their contribution to the reduction of light reaching the plant often exceeds that of phytoplankton (Roberts, Kroker, Körner, \& Nicklisch, 2003). On the other hand, common epiphytic species might have developed resistance against allelochemicals from submerged plants in the same habitat by co-evolution (Reigosa, SanchezMoreiras, \& Gonzalez, 1999). Only a few studies tested the influence of macrophytes or allelopathic substances on epiphytic and planktonic algae using the same method (Erhard \& Gross, 2006; Gross, 1995; Hilt, 2006; Nakai et al., 1999; Wium-Andersen, Anthoni, Christophersen, \& Houen, 1982). Epiphytic algae, even species closely related to suspended phytoplankton species, were always less sensitive than planktonic species, or were not inhibited at all. The lower vulnerability of epiphytes to allelochemicals is supported by a literature survey (Hilt, 2006; Hilt et al., 2006; Mulderij, Mooij, Smolders, et al., 2005; Mulderij, Mau, et al., 2007). More planktonic than epiphytic species were significantly inhibited, according to the analysis of the reaction of species from both groups towards macrophyte allelochemicals by a $2 \times 2 \chi^{2}$-test; $p<0.05$ (Fig. 4). Final proof for this difference, however, requires further studies, e.g., comparing the sensitivity of epiphytic species originating from submerged macrophytes with different allelopathic activity, or comparing epiphytes from different habitats.

\section{Impact of resources on phytoplankton sensitivity to macrophyte allelochemicals}

Resource availability does not only influence the production and release of allelochemicals but also the sensitivity of phytoplankton. Allelopathic interactions should be enhanced under stress, e.g., nutrient limitation (Reigosa et al., 1999). The inhibition of extracellular alkaline phosphatase (APA) has been proposed as one mode of action of allelopathically active polyphenols (Gross et al., 1996). APA is produced by many algae and cyanobacteria during periods of inorganic phosphate limitation, even occurring in eutrophic shallow lakes during summer (Vrba, Komarkova, \& Vyhnalek, 1993). Phytoplankton of eutrophic shallow lakes may therefore be especially sensitive against allelopathic polyphenols during periods of phosphate limitation. Submerged macrophytes and their epiphyton leak phosphorus mostly during decomposition (Carignan \& Kalff, 1982; Smith \& Adams, 1986), but potentially also when alive 


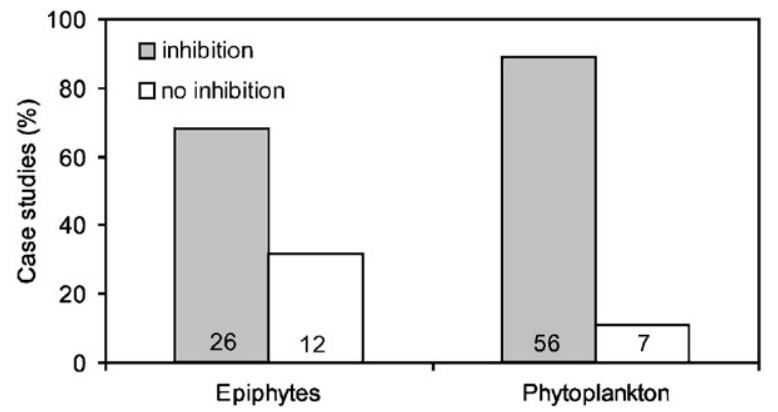

Fig. 4. Frequency of studies showing different allelopathic effects of submerged macrophytes on epiphytes versus phytoplankton (data from Hilt, 2006; Hilt et al., 2006; Mulderij, Mooij, et al., 2005; Mulderij, Mau, et al., 2007). Total case numbers are given at the base of the bars.

and healthy (Lombardo \& Cooke, 2003; Pomogyi, Best, Dassen, \& Boon, 1984). A combined effect of allelochemicals and phosphorus leakage was supposed to explain lower allelopathic effects of $M$. verticillatum on two cyanobacteria under phosphorus deficiency (Hilt, 2006; Hilt et al., 2006). In situ, probably both, net inhibition or enhancement of the phytoplankton growth in plant stands may occur depending on the ratio between the release of allelochemicals and phosphates by the macrophytes.

\section{Conclusions}

Allelopathy can contribute to the stabilisation of clear-water states in shallow lakes, when proven allelopathically active species such as Myriophyllum, Ceratophyllum, Elodea, Najas or certain Characeae dominate the submerged vegetation, and when phytoplankton growth is the main reason for turbid conditions. Allelopathically induced growth inhibition of phytoplankton can occur when macrophytes infest a large part of the lake volume, when within patches plant density is high $\left(>100 \mathrm{gdry}\right.$ mass $\mathrm{m}^{-2}$ ) and when sensitive species such as diatoms and cyanobacteria dominate the phytoplankton. Whether additional stress such as phosphorus limitation will result in a stronger inhibition of phytoplankton due to inhibition of APA or if this effect is mediated by phosphorus leakage from the plants has to be explored in further experiments. Epiphytes appear less sensitive to macrophyte allelochemicals, and their shading can contribute significantly to submerged macrophyte loss with increasing nutrient concentrations.

We need more information on the identity and amount of allelopathically active compounds, and factors influencing their production by and release from macrophytes. Since apparently only a continuous release of allelochemicals affects phytoplankton species, we need more information about bacterial and photolytic degradation of allelochemicals. The differential sensitivity of phytoplankton functional groups and species against active substances has implications for the density and composition of the phytoplankton community in lakes dominated by allelopathically active macrophytes. Despite many open questions, existing knowledge indicates in situ relevance of allelopathy in the alternating stable states in shallow eutrophic lakes. Combined studies addressing various levels of complexity are required for further proof.

\section{Acknowledgements}

We thank all students, technicians and colleagues from the Leibniz-Institute of Freshwater Ecology and Inland Fisheries in Berlin and Neuglobsow and the University of Konstanz who have been involved in our studies during the previous years. Gerben van Geest kindly provided macrophyte data from The Netherlands. Jürgen Matthes and Ilona Korczynski fortunately contributed morphological data of lakes in Mecklenburg-Western Pomerania. We were financially supported by the German Research Foundation and the "Berliner Programm zur Förderung der Chancengleichheit von Frauen in Forschung und Lehre". A previous version of this manuscript benefited from very valuable comments by Paola Lombardo, Klaus Hövemeyer and an anonymous reviewer.

\section{References}

Aliotta, G., Molinaro, A., Monaco, P., Pinto, G., \& Previtera, L. (1992). Three biologically active phenylpropanoid gluco sides from Myriophyllum verticillatum. Phytochemistry, 31, 109111.

Anthoni, U., Christophersen, C., Madsen, J., Wium Andersen, S., \& Jacobsen, N. (1980). Biologically active sulphur compounds from the green algae Chara globularis. Phy tochemistry, 19, 12281229.

Appel, H. M. (1993). Phenolics in ecological interactions The importance of oxidation. Journal of Chemical Ecology, 19, 15211552.

Berger, J., \& Schagerl, M. (2003). Allelopathic activity of Chara aspera. Hydrobiologia, 501, 109115.

Berger, J., \& Schagerl, M. (2004). Allelopathic activity of Characeae. Biologia, 59, 915.

Best, E. P. H., \& Meulemans, J. T. (1979). Photosynthesis in relation to growth and dormancy in Ceratophyllum demersum. Aquatic Botany, 6, 5365.

Blindow, I. (1992). Decline of charophytes during eutrophica tion: Comparison with angiosperms. Freshwater Biology, $28,914$.

Blindow, I., Hargeby, A., \& Andersson, G. (2002). Seasonal changes of mechanisms maintaining clear water in a 
shallow lake with abundant Chara vegetation. Aquatic Botany, 72, 315334.

Bryant, J. P., Chapin, F. S., III, \& Klein, D. R. (1983). Carbon/nutrient balance of boreal plants in relation to vertebrate herbivory. Oikos, 40, 357368.

Canfield, D. E., Shireman, J. V., Colle, D. E., Haller, W. T., Watklins, C. E., \& Maceina, M. J. (1984). Prediction of chlorophyll $a$ concentrations in Florida lakes: Importance of aquatic macrophytes. Canadian Journal of Fisheries and Aquatic Sciences, 41, 497501.

Carignan, R., \& Kalff, J. (1982). Phosphorus release by submerged macrophytes: Significance to epiphyton and phytoplankton. Limnology and Oceanography, 27, 419427.

Casamatta, D. A., \& Wickstrom, C. E. (2000). Sensitivity of two disjunct bacterioplankton communities to exudates from the cyanobacterium Microcystis aeruginosa Kützing. Microbial Ecology, 40, 6473.

Choi, C., Bareiss, C., Walenciak, O., \& Gross, E. M. (2002). Impact of polyphenols on the growth of the aquatic herbivore Acentria ephemerella (Lepidoptera: Pyralidae). Journal of Chemical Ecology, 28, 22232235.

Elakovich, S. D., \& Wooten, J. W. (1995). Allelopathic, herbaceous, vascular hydrophytes. In Inderjit, K. M. M. Dakshini, \& F. A. Einhellig (Eds.), Allelopathy Organisms, processes, and applications (pp. 58 73). Washington, DC: ACS Symposium Series 582, American Chemical Society.

Erhard, D., \& Gross, E. M. (2006). Allelopathic activity of Elodea canadensis and E. nuttallii against epiphytes and phytoplankton. Aquatic Botany, 85, 203211.

Farjalla, V. F., Anesio, A. M., Bertilsson, S., \& Graneli, W. (2001). Photochemical reactivity of aquatic macrophyte leachates: Abiotic transformations and bacterial response. Aquatic Microbial Ecology, 24, 187195.

Grace, J. B., \& Wetzel, R. G. (1978). The production biology of Eurasian watermilfoil (Myriophyllum spicatum L.): A review. Journal of Aquatic Plant Management, 16, 111.

Graneli, W., Lindell, M., \& Tranvik, L. (1996). Photo oxidative production of dissolved inorganic carbon in lakes of different humic content. Limnology and Oceanography, 41, 698706 .

Gross, E. M. (1995). Allelopathische Interaktionen submerser Makrophyten mit Epiphyten und Phytoplankton: Algizide hydrolisierbare Polyphenole aus Myriophyllum spicatum L. Göttingen: Cuvillier.

Gross, E. M. (2000). Seasonal and spatial dynamics of allelochemicals in the submersed macrophyte Myriophyllum spicatum L. Verhandlungen Internationale Vereinigung Limnologie, 27, 21162119.

Gross, E. M. (2003a). Allelopathy of aquatic autotrophs. Critical Reviews in Plant Sciences, 22, 313339.

Gross, E. M. (2003b). Differential response of tellimagrandin II and total bioactive hydrolysable tannins in an aquatic angiosperm to changes in light and nitrogen. Oikos, 103, 497504.

Gross, E. M., Erhard, D., \& Ivanyi, E. (2003). Allelopathic activity of Ceratophyllum demersum L. and Najas marina ssp. intermedia. Hydrobiologia, 506, 583589.

Gross, E. M., Hilt, S., Lombardo, P., \& Mulderij, G. (2007). Searching for allelopathy in action State of the art and open questions. Hydrobiologia, 584, 7788.
Gross, E. M., Meyer, H., \& Schilling, G. (1996). Release and ecological impact of algicidal hydrolyzable polyphenols in Myriophyllum spicatum. Phytochemistry, 41, 133138.

Heegaard, E., Birks, H. H., Gibson, C. E., Smith, S. J., \& Wolfe Murphy, S. (2001). Species environmental relation ships of aquatic macrophytes in Northern Ireland. Aquatic Botany, 70, 175223.

Hilt, S. (2006). Allelopathic inhibition of epiphytes by submerged macrophytes. Aquatic Botany, 85, 252256.

Hilt, S., Ghobrial, M. G. N., \& Gross, E. M. (2006). In situ allelopathic potential of Myriophyllum verticillatum (Halor agaceae) against selected phytoplankton species. Journal of Phycology, 42, 11891198.

Hootsmans, M. J. M., \& Blindow, I. (1994). Allelopathic limitation of algal growth by macrophytes. In W. Van Vierssen, M. J. M. Hootsmans, \& J. E. Vermaat (Eds.), Lake Veluwe, a macrophyte dominated system under eu trophication stress (pp. 175 192). Dordrecht: Kluwer.

Inderjit, \& Del Moral, R. (1997). Is separating resource competition from allelopathy realistic? Botanical Review, 63, 221230 .

Jasser, I. (1995). The influence of macrophytes on a phytoplankton community in experimental conditions. Hydrobiologia, 306, 2132.

Jeppesen, E., Jensen, J. P., Kristensen, P., Søndergaard, M., Mortensen, E., Sortkjær, O., et al. (1990). Fish manipula tion as a lake restoration tool in shallow, eutrophic, temperate lakes 2: Threshold levels, long term stability and conclusions. Hydrobiologia, 200/201, 219227.

Jeppesen, E., Jensen, J. P., Søndergaard, M., \& Lauridsen, T. L. (1999). Trophic dynamics in turbid and clearwater lakes with special emphasis on the role of zooplankton for water clarity. Hydrobiologia, 408/409, 217231.

Jeppesen, E., Søndergaard, M., Jensen, J. P., Havens, K., Anneville, O., Carvalho, L., et al. (2005). Lake responses to reduced nutrient loading An analysis of contemporary data from 35 European and North American long term studies. Freshwater Biology, 50, 17471771.

Jones, J. I., Eaton, J. W., \& Hardwick, K. (2000). The influence of periphyton on boundary layer conditions: A $\mathrm{pH}$ micro electrode investigation. Aquatic Botany, 67, 191206.

Jones, J. I., \& Sayer, C. (2003). Does fish invertebrate per iphyton cascade precipitate plant loss in shallow lakes? Ecology, 84, 215521767.

Körner, S. (2001). Development of submerged macrophytes in shallow Lake Müggelsee (Berlin, Germany) before and after its switch to the phytoplankton dominated state. Archiv für Hydrobiologie, 152, 395409.

Körner, S. (2002). Loss of submerged macrophytes in shallow lakes in North Eastern Germany. International Revue of Hydrobiology, 87, 375384.

Köhler, J., Hilt, S., Adrian, R., Kozerski, H. P., Nicklisch, A., \& Walz, N. (2005). Long term response of a shallow, moderately flushed lake to reduced external phosphorus and nitrogen loading. Freshwater Biology, 50, 16391650.

Körner, S., \& Nicklisch, A. (2002). Allelopathic growth inhibition of selected phytoplankton species by submerged macrophytes. Journal of Phycology, 38, 862871.

Kogan, S. I., \& Chinnova, G. A. (1972). Relations between Ceratophyllum demersum (L.) and some blue green algae. 
Hydrobiological Journal (Ghidrobiol. Zh.), 8, 1419 (21 27).

Lau, S. S. S., \& Lane, S. N. (2002). Nutrient and grazing factors in relation to phytoplankton level in a eutrophic shallow lake: The effect of low macrophyte abundance. Water Research, 36, 35933601.

Lauridsen, T., Pedersen, L. J., Jeppesen, E., \& Søndergaard, M. (1996). The importance of macrophyte bed size for composition and horizontal migration of cladocerans in a shallow lake. Journal of Plankton Research, 18, 22832294.

Leske, S., Berg, C., Kabus, T., \& Täuscher, L. (2005). Bibliographie Submerse Makrophyten in Seen Mecklen burg Vorpommerns. Botanischer Rundbrief für Mecklen burg Vorpommern, 40, 79104.

Leu, E., Krieger Liszkay, A., Goussias, C., \& Gross, E. M. (2002). Polyphenolic allelochemicals from the aquatic angiosperm Myriophyllum spicatum L. inhibit photosystem II. Plant Physiology, 130, 20112018.

Lombardo, P. (2005). Applicability of littoral food web biomanipulation for lake management purposes: Snails: macrophytes, and water transparency in northeast Ohio shallow lakes. Lake and Reservoir Management, 21, 186202.

Lombardo, P., \& Cooke, G. D. (2003). Ceratophyllum demersum Phosphorus interactions in nutrient enriched aquaria. Hydrobiologia, 497, 7990.

Meijer, M. L., Jeppesen, E., Van Donk, E., Moss, B., Scheffer, M., Lammens, E., et al. (1994). Long term responses to fishstock reduction in small shallow lakes: Interpretation of five year results of four biomanipulation cases in The Netherlands and Denmark. Hydrobiologia, 275/276, 457466.

Mjelde, M., \& Faafeng, B. A. (1997). Ceratophyllum demersum hampers phytoplankton development in some small Nor wegian lakes over a wide range of phosphorus concentra tions and geographical latitude. Freshwater Biology, 37, 355365.

Moss, B., Madgwick, J., \& Phillips, G. (1997). A guide to the restoration of nutrient rich Shallow Lakes. Norwich: Broads Authority.

Müller, N., Hempel, M., Philipp, B., \& Gross, E. M. (2007). Degradation of gallic acid and hydrolysable polyphenols is constitutively activated by the freshwater plant associated bacterium Matsuebacter sp. FB 25. Aquatic Microbial Ecology, 47, 8390.

Mulderij, G. (2006). Chemical warfare in freshwater Allelopathic effetcs of macrophytes on phytoplankton. Ph.D. thesis, Netherlands Institute of Ecology, The Nether lands.

Mulderij, G., Van Donk, E., \& Roelofs, J. G. M. (2003). Differential sensitivity of green algae to allelopathic substances from Chara. Hydrobiologia, 491, 261271.

Mulderij, G., Mooij, W. M., Smolders, A. J. P., \& Van Donk, E. (2005). Inhibition of phytoplankton by allelopathic substances from Stratiotes aloides. Aquatic Botany, 82, 284296.

Mulderij, G., Mooij, W. M., \& Van Donk, E. (2005). Allelopathic growth inhibition and colony formation of the green alga Scenedesmus obliquus by the aquatic macrophyte Stratiotes aloides. Aquatic Ecology, 39, 1121.
Mulderij, G., Smolders, A. J. P., \& Van Donk, E. (2006). The allelopathic effect of Stratiotes aloides on phytoplankton under natural conditions. Freshwater Biology, 51, 554562.

Mulderij, G., Mau, B., Van Donk, E., \& Gross, E. M. (2007). Allelopathic activity of Stratiotes aloides on phytoplankton

Towards identification of allelopathic substances. Hydro biologia, 584, 89100.

Mulderij, G., Van Nes, E., \& Van Donk, E. (2007). Macrophyte Phytoplankton interactions: The relative importance of allelopathy versus other factors. Ecological Modelling, 204, 8592.

Nakai, S., Inoue, Y., Hosomi, M., \& Murakami, A. (1999). Growth inhibition of blue green algae by allelopathic effects of macrophytes. Water Science and Technology, 39, 4753.

Nakai, S., Inoue, Y., \& Hosomi, M. (2001). Allelopathic effects of polyphenols released by Myriophyllum spicatum on the growth of cyanobacterium Microcystis aeruginosa. Allelopathy Journal, 8, 201210.

Nakai, S., Inoue, Y., Hosomi, M., \& Murakami, A. (2000). Myriophyllum spicatum released allelopathic polyphenols inhibiting growth of blue green algae Microcystis aerugi nosa. Water Research, 34, 30263032.

Ozimek, T., Prejs, K., \& Prejs, A. (1986). Biomass and growth rate of Potamogeton pectinatus in lakes of different trophic state. Ecologia Polska, 34, 125131.

Phillips, G. L., Eminson, D., \& Moss, B. (1978). A mechanism to account for macrophyte decline in progressively eu trophicated freshwaters. Aquatic Botany, 4, 103126.

Planas, D., Sarhan, F., Dube, L., Godmaire, H., \& Cadieux, C. (1981). Ecological significance of phenolic compounds of Myriophyllum spicatum. Verhandlungen Internationale Ver einigung Limnologie, 21, 14921496.

Pomogyi, P., Best, E. P. H., Dassen, J. H. A., \& Boon, J. J. (1984). On the relation between age, plant composition and nutrient release from living and killed Ceratophyllum plants. Aquatic Botany, 19, 243250.

Portielje, R., \& Van der Molen, D. T. (1999). Relationships between eutrophication variables: From nutrient loading to transparency. Hydrobiologia, 408/409, 375387.

Reigosa, M. J., Sanchez Moreiras, A., \& Gonzalez, L. (1999). Ecophysiological approach in allelopathy. Critical Reviews in Plant Sciences, 18, 577608.

Roberts, E., Kroker, J., Körner, S., \& Nicklisch, A. (2003). The role of periphyton during the re colonization of a shallow lake with submerged macrophytes. Hydrobiologia, 506, 525530 .

Ruggiero, A., Solimini, A. G., \& Carchini, G. (2003). Nutrient and chlorophyll $a$ temporal patterns in eutrophic mountain ponds with contrasting macrophyte coverage. Hydrobiolo gia, 506509,657663 .

Sand Jensen, K., Riis, T., Vestergaard, O., \& Larsen, S. E. (2000). Macrophyte decline in Danish lakes and streams over the last 100 years. Journal of Ecology, 88, 10301040.

Scheffer, M., Hosper, S. H., Meijer, M. L., Moss, B., \& Jeppesen, E. (1993). Alternative equilibria in shallow lakes. Trends in Ecology and Evolution, 8, 275279.

Smith, C. S., \& Adams, M. S. (1986). Phosphorus transfer from sediments by Myriophyllum spicatum. Limnology and Oceanography, 31, 13121321. 
Stamp, N. (2003). Out of the quagmire of plant defense hypotheses. Quarterly Review of Biology, 78, 2355.

Van den Berg, M. S., Coops, H., Meijer, M. L., Scheffer, M., \& Simons, J. (1998). Clear water associated with a dense Chara vegetation in the shallow and turbid lake Veluwem eer, The Netherlands. In E. Jeppesen, Ma. Søndergaard, Mo. Søndergaard, \& K. Christoffersen (Eds.), The structur ing role of submerged macrophytes in lakes (pp. 339 352). New York: Springer.

Van Donk, E., \& Van de Bund, W. J. (2002). Impact of submerged macrophytes including charophytes on phyto and zooplankton communities: Allelopathy versus other mechanisms. Aquatic Botany, 72, 261274.

Van Geest, G., Coops, H., Roojackers, R. M. M., Buijse, A. D., \& Scheffer, M. (2005). Succession of aquatic vegetation driven by reduced water level fluctuations in floodplain lakes. Journal of Applied Ecology, 42, 251260.

Van Wijk, R. J. (1988). Ecological studies on Potamogeton pectinatus L.I. General characteristics, biomass production and life cycles under field conditions. Aquatic Botany, 31, 211258.

Vestergaard, O., \& Sand Jensen, K. (2000). Alkalinity and trophic state regulate aquatic plant distribution in Danish lakes. Aquatic Botany, 67, 85107.
Vrba, J., Komarkova, J., \& Vyhnalek, V. (1993). Enhanced activity of alkaline phosphatases phytoplankton response to epilimnetic phosphorus depletion. Water Science and Technology, 28, 1524.

Walenciak, O., Zwisler, W., \& Gross, E. M. (2002). Influence of Myriophyllum spicatum derived tannins on gut micro biota of its herbivore Acentria ephemerella. Journal of Chemical Ecology, 28, 20452056.

Wetzel, R. G. (1990). Land water interfaces: Metabolic and limnological regulators. Verhandlungen Internationale Ver einigung Limnologie, 24, 624.

Willis, R. J. (1985). The historical bases of the con cept of allelopathy. Journal of the History of Biology, 18, 71102.

Wium Andersen, S., Anthoni, U., Christophersen, C., \& Houen, G. (1982). Allelopathic effects on phytoplankton by substances isolated from aquatic macrophytes (Char ales). Oikos, 39, 187190.

Wium Andersen, S., Anthoni, U., \& Houen, G. (1983). Elemental sulphur, a possible allelopathic compound from Ceratophyllum demersum. Phytochemistry, 22, 2613.

Wium Andersen, S. (1987). Allelopathy among aquatic plants. Archiv für Hydrobiologie, Beihefte Ergebnisse der Limnolo gie, 27, 167172. 